\title{
Role of exosomal proteins in cancer diagnosis
}



\begin{abstract}
Exosomes are emerging as a new type of cancer biomarkers. Exosome is a bilayered nano-sized vesicle secreted by various living cells in all body fluids. Based on the expanding albeit incomplete knowledge of their biogenesis, secretion by cells and cancer cell-specific molecular and genetic contents, exosomes are viewed as promising, clinically-relevant surrogates of cancer progression and response to therapy. Preliminary proteomic, genetic and functional profiling of cancer cell-derived or cancer plasma-derived exosomes confirms their unique characteristics. Alterations in protein or nucleic acid profiles of exosomes in plasma correlate with pathological processes of many diseases including cancer. However, previous studies on exosome application in cancer diagnosis and treatment mainly focussed on miRNAs. With the development of rapid large-scale production, purification, extraction and screening of exosomal contents, exosomal protein application can be explored for early stage cancer diagnosis, monitoring and prognosis evaluation. Here, we summarized the recent developments in application of exosomal proteins for cancer diagnosis.
\end{abstract}

Keywords: Exosome, Cancer, Diagnose, Biomarker

\section{Background}

Cancer is a major public health problem worldwide. Early cancer diagnosis and general awareness of risk factors for cancer have clearly improved survival. However, there is an urgent need to identify more effective and less invasive surrogate markers, which could guide early diagnosis, choice of therapeutic strategies for individual patients, and accurate estimates of prognosis.

Exosomes are produced by a number of cell types. Exosome secretion was described to originate from haematopoietic cells such as reticulocytes [1-3], B lymphocytes and T cells $[1,4-9]$, platelets $[1,4,6-10]$, mast cells $[1,4,6-9$, $11]$, dendritic cells $[1,4,6-8]$ and macrophages $[12,13]$. Exosomes are also produced by the cells of nonhaematopoietic origin like epithelial cells (intestinal epithelial cells) $[1,6,14-21]$, astrocytes $[1,22]$, neurons $[1,22]$, melanocytes [12], mesothelioma cells [6], adipocytes [23], fibroblasts [23] and tumour cells [1, 6, 14, 17-21]. Exosomes have also been identified in most bodily fluids including urine and amniotic fluid [24], blood [25], serum

\footnotetext{
* Correspondence: lixiuhui@sohu.com; dexichen@ccmu.edu.cn

Weihua Li and Chuanyun Li are co-first author.

${ }^{1}$ YouAn Hospital, Capital Medical University, Beijing, China

${ }^{2}$ Beijing Institute of Hepatology, Beijing, China

Full list of author information is available at the end of the article
}

[26, 27], saliva [28, 29], ascites [30], breast milk [31], cerebrospinal fluid [32, 33] and nasal secretion [34, 35]. They play an essential role in intercellular communication by carrying their contents. Exosomes reflect the phenotypic state of the parental cell. Intercellular communication mediated by exosomes not only participates in the regulation of normal physiological processes but also in pathological processes of many diseases, including cancer [36-38].

Due to their presence and stability in most body fluids and resemblance of their contents to parental cells, exosomes have great potential as liquid biopsy specimens for various diseases [39, 40]. In particular, cancer-derived exosomes likely serve as biomarkers for early detection of cancer as they carry the cargo reflective of genetic or signaling alterations in cancer cells of origin [41-43]. The objective of this review was to consider the evidence in support of the potential role of cancer-derived exosomes as biomarkers, which in the near future might facilitate monitoring of cancer progression and its outcome.

\section{Biogenesis and characteristics of exosomes}

Exosomes are 40-100 nm extracellular vesicles (EVs), $1.13-1.19 \mathrm{~g} / \mathrm{mL}$ in density, with a classic "cup" or "dish" morphology [44]. According to the current version of 
the exosome content database, Exocarta (http:// www.exocarta.org), 9769 proteins, 1116 lipids, 3408 mRNAs and 2838 microRNAs have been identified in exosomes of many different cell types and from multiple organism, thus demonstrating their complexity once again [45-47]. The exosomal contents vary between different physiological and pathological conditions and original cell types. Moreover, the composition of exosomes can be distinct from the originated cells due to the selective sorting of the cargo into exosomes. These proteins included constitutive components of exosomes such as tetraspanins (CD9, CD63, CD81, CD82, CD151, Tspan8), [48, 49] cell type-specific molecules such as histocompatibility complex (MHC) class-I and class-II and other molecules such as adhesion molecules, proteases, MHC molecules, HSP60, HSP70 and HSP90, the ESCRT components TSG101 and Alix $[44,50,51]$. In addition to proteins and lipids, exosomes contain large amounts of nucleic acids, such as mRNA, microRNA, circular RNA, long non-coding RNA and DNA, which are protected from degradation due to the double lipid membrane [43, 52-55]. Here, the structure and contents of exosomes is demonstrated in Fig. 1.

Exosome formation is a fine-tuned process which includes four stages: initiation, endocytosis, multivesicular bodies (MVBs) formation, and exosome secretion [44] Multivesicular bodies (MVBs) are endocytic structures formed by the budding of an endosomal membrane into the lumen of the compartment [56]. After vesicular accumulation, the MVBs are either sorted for cargo degradation in the lysosome or released into the extracellular space as exosomes by fusing with the plasma membrane (Fig. 1). The mechanisms underlying the sorting of cargo into the intraluminal vesicles (ILVs) are not yet fully elucidated. Both endosomal sorting complex required for transport (ESCRT)-dependent and independent signals have been suggested to determine the sorting of exosomes [57]. The formation of exosomes has been shown to be controlled by the syndecan heparan sulfate proteoglycans and their cytoplasmic adaptor syntenin [58].

Several mechanisms have been suggested to mediate the uptake of exosomes, including a exosome fusion with the cellular membrane of the recipient cell, leading to the release of the exosomal cargo into the cytoplasm, juxtracrine signaling through receptor-ligand interactions, and endocytosis by phagocytosis (Fig. 1). Although the specific receptors that mediate the uptake of exosomes have not been found, there are several proteins that may act as potential receptors for exosome uptake, such as Tim1/4 for B cells [59] and ICAM-1 for APCs [60].

\section{Exosome - Functions in cancer}

Exosomes play a very important role in cancer progression, metastasis, and therapeutic efficacy. The role of exosomes in cancer development is of particular interest to oncologists because cancer cells secrete at least 10-fold more exosomes than normal cells, Exosomes are involved in initiation, growth, progression and drug-resistance of cancers involving interactions with the microenvironment by transferring oncogenic proteins and nucleic acids [6164]. First, Exosome promote angiogenesis and metastasis: Exosome uptake induces upregulation of angiogenesis related genes and results in enhanced endothelial cell proliferation, migration, and sprouting [65]. Exosomes derived from hypoxic glioblastoma cells are more potent to induce angiogenesis [66]. Cancer exosomes are responsible for stromal activation [67], induction of the angiogenic switch [68-72], increased vascular permeability [42, 43, 73, 74]. Exosome contribute to metastasis by aiding in the epithelialtomesenchymal transition and formation of the premetastatic niche [75-77]. Second, Exosome contribute to cancer-associated fibroblasts [78-80]. exosomes derived from MDA-MB 231 breast cancer cells and U87 glioblastoma cells were able to induce transformation of recipient fibroblasts, dependent on continuous supply of exosomes [81]. The phenomenon is caused by tissue transglutaminase cross-linked fibronectin (FN) in cancer vesicles, which activates mitogenic signaling. Third, Exosome can lead to immune escape: The generation of an immuno-suppressive environment is an important issue for the pathogenesis of cancers. Exosomes have been shown to be implicated in induction of apoptosis of cytotoxic T-cells, expansion and function of regulatory T-cells (Tregs), induction of M2 polarization of macrophages, inhibition of cytotoxicity of natural killer (NK) cells, inhibition of differentiation of dendritic cells (DC), expansion and activation of myeloidderived suppressor cells (MDSC) and mobilization of neutrophils [82-85]. Finally, exosomes protect cancer cells from the cytotoxic effects of chemotherapy drugs and transfer chemoresistance properties to nearby cells [86, 87]. Transfer of multi-drug resistant protein Pgp to drug-sensitive cells conferring drug-resistent properties and directing cytotoxic drugs such as cisplatin away from the nucleus have been reported [88, 89] (Fig. 2). Stromal derived exosomes were shown to regulate therapy resistance pathways in breast cancer cells [90]. Expansion of chemotherapy-resistant cancer cells was mediated by activation of the pattern recognition receptor RIG-1, which triggers STAT-1 signaling (antiviral) and induces the interaction of stromal JAG-1 with Notch3 on breast cancer cells [90].

\section{Potential of exosomal proteins in disease diagnosis and prognosis prediction}

Exosome contains abundant proteins. In addition to selfproteins, it also contains proteins derived from cells. Exosomal proteins from cancer cells are becoming new biomarkers for cancer monitoring and efficacy evaluation based on the following characteristics: 1) Cancer- 


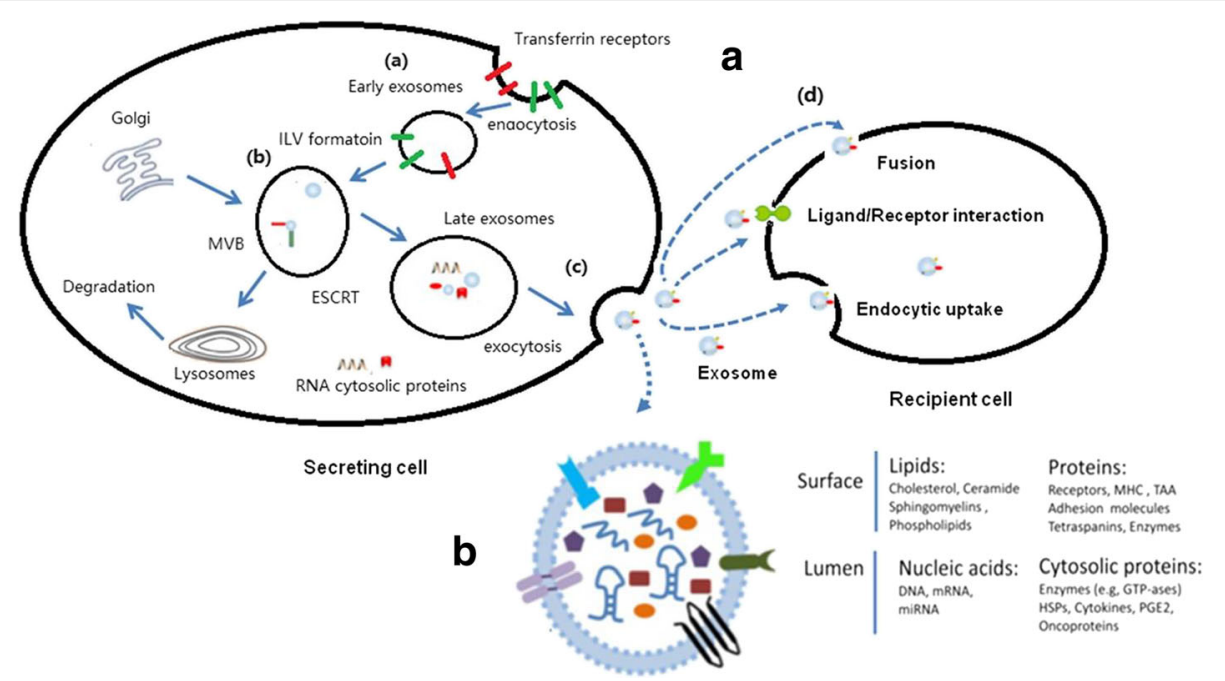

Fig. 1 Biogenesis, release, structure, and uptake of exosomes. In A, exosomes are repressed by small vesicles of different sizes that are formed as the ILV by budding into early endosomes and multivesicular body and are released by fusion of multivesicular body fuse with lysosomes. (a). By endocytosis of membrane segments, the initial endosome arises, containing receptors and transmembrane proteins of the plasma membrane. (b). Instead of lysosomal degradation, the matured late endosome transforms by inward budding of tiny vesicles into a multivesicular body. Furthermore, the exosomal cargo as proteins and miRNA, is selectively loaded into the vesicles. (c). Exosomes are released into the extracellular space by fusion of the multivesicular body with the plasma membrane. (d). Cell-secreted exosomes can travel through biological fluids (e.g. serum, lymph) and be internalized by recipient cells. Exosomes transfer information to the target cells through three main ways: (1) direct fusion with plasma membrane; (2) receptor-ligand interaction; (3) endocytosis by phagocytosis. In B, The membrane of the MVBs bulges inward to form exosomes. During this process, proteins (e.g., receptor, cytoplasmic proteins, tetraspanin), nucleic acids (e.g., DNA, mRNA, miRNA), and lipids (e.g., cholesterol, ceramide) are packed into exosomes in a cell type-dependent manner

related lipid, protein, RNA and DNA in exosomes can be used to test for cancers [91]. 2) Small volume, strong permeability through body tissue barrier and wide existence in various body fluids make exosomes easily accessible for clinical detection [92].3) Lipid bilayer membrane structure of the exosome protects its contents from degradation by enzymes in blood circulation. Phosphorylation proteins can be separated from exosomal samples frozen for 5 years. 4) The components of blood are complex, and specific proteins secreted by cancer cells are diluted in blood, so a cancer protein will not be easily detected at an early stage or when its amount is lower. In each milliliter of human blood, there are over $10^{9}$ exosomes. After purification, reasonable numbers of exosomes can be obtained, and cancer-derived exosomes can also be collected. Thus, in vivo detection of exosomes is highly sensitive and conducive to diagnosis of early stage cancer [93]. Based on the above characteristics, detecting exosomal proteins as biomarkers for cancer diagnosis and prognosis evaluation possesses tremendous potential.

\section{Correlation between exosomal proteins as biomarkers and respiratory disease \\ Lung cancer}

Lung cancer is one of the most common cancers in men and women. An important problem in the diagnosis of lung cancer is the lack of a universal biomarker(s) for early diagnosis. Close to $70 \%$ of patients with lung cancer present locally advanced or metastatic disease at the time of diagnosis. Recent studies suggest that exosomes can be potentially useful new tools [94]. Exocrine plays an important role in the occurrence, development and metastasis of lung cancer (Fig. 3). Exosomes secreted by platelets have demonstrated to promote cancer growth and metastasis of lung cancer cells [95]. Grange and colleagues showed that exosomes released from renal cells can promote angiogenesis in lung cancer ascites [96]. That information may be crucial for cancer progression and angiogenesis according to a recent published research showing the involvement of cancer cells-released exosomes in that matter [97] (Fig. 3). Exosomes have been shown to be involved in several cellular functions and intrinsic mechanisms of cancer where they possibly constitute valuable biomarkers [98]. Clark D et al. [99] found that various protein components accumulated in exosomes secreted by lung cancer cells, which could promote the occurrence of lung cancer and facilitate early stage diagnosis. Jakobsen et al. [100] reported that CD317 and epidermal growth factor receptor (EGFR) were highly expressed on exosomal surface, by analyzing the extracellular vesicles secreted by lung cancer cells. These molecules are reliable biomarkers for diagnosing non-small cell lung cancer (NSCLC). Li et al. [101] 


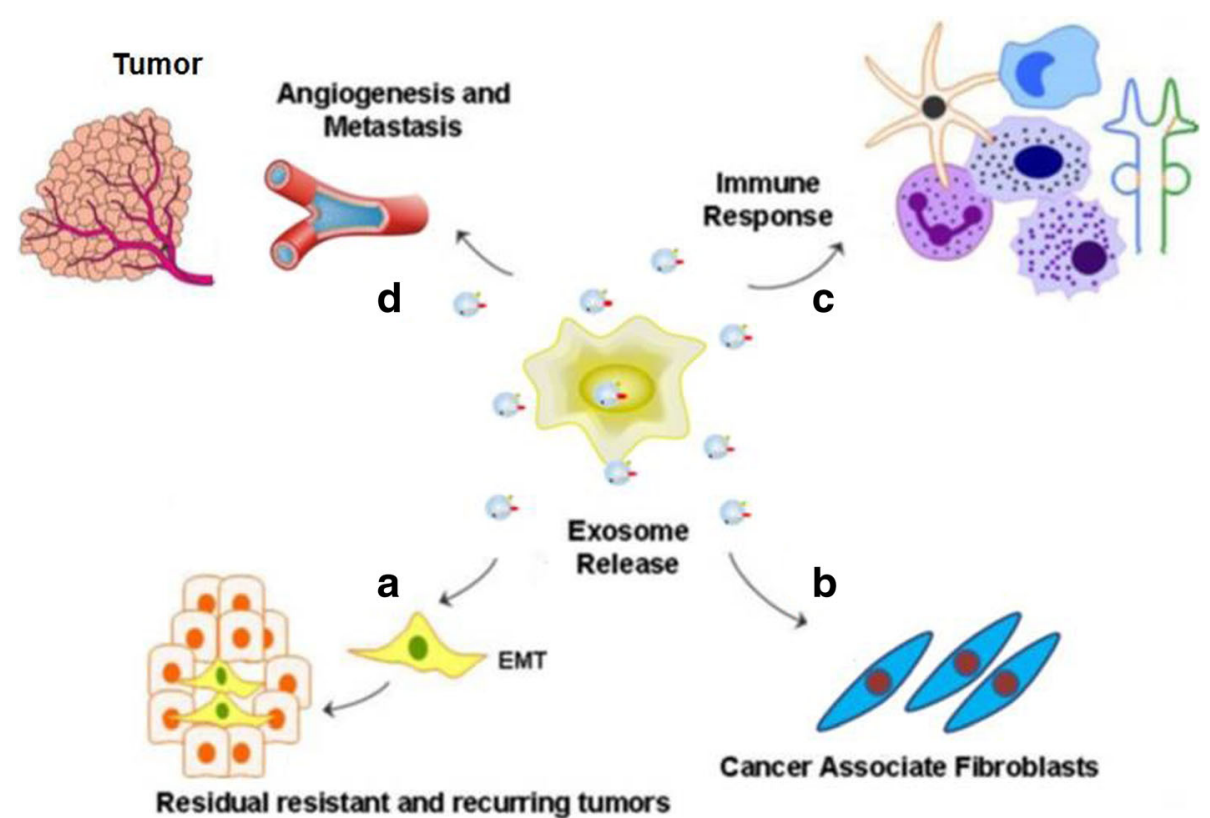

Fig. 2 Role of exosomes in sustaining cancer resistance networks. Exosome mediated export of biological material can induce a microenvironment favorable for resistance. Exosome released factor can promote $\mathbf{a}$ EMT cell morphology, resulting in stemness; $\mathbf{b}$ promote fibroblast like cell formation that causes desmoplatic reaction (stromal reaction); c promote immune escape mechanisms and $\mathbf{d}$ promote angiogenesis and metastasis. The miRNAs expelled by exosomes can regulate multiple signaling pathways that cumulatively promote resistant phenotype of most tumors

found that human leucine rich alpha-2-glycoprotein 1 (LRG1) in urinary exosomes was a potential biomarker for diagnosing NSCLC. Proteomic mass spectrometry showed that LRG1 accumulated in urinary exosomes, and was significantly highly expressed in NSCLC patients as compared to healthy individuals. Furthermore, they also reported that LRG1 protein was highly expressed in cancer tissues. Therefore, LRG1 protein in urinary exosomes was derived from cancer tissues. Sandfeld et al. [102] used 49 antibodies to detect exosomal proteins from 431 lung cancer patients and 150 healthy individuals. They found that CD171, CD151 and tetraspanin 8 were significantly highly expressed in patients as compared to healthy individuals. In squamous-cell carcinoma and small-cell lung cancer patients, CD151 is also an independent biomarker. Recently, exosomes in peripheral blood were reported to contain 30 specific biomarkers. Therefore, exosomes and their related components provide a theoretical basis for exploring molecular biomarkers for early stage lung cancer diagnosis.

\section{Nasopharyngeal cancer}

Keryer et al. [103] first detected latent membrane protein 1 (LMP1) in exosomes from nasopharyngeal cell lines infected with Epstein Barr virus (EBV) in 2006. They found that nasopharyngeal cancer cells could release HLA II and exosomes containing galectin 9 and/or LMP1. LMP1 could inhibit T cell viability. Klibi et al. [104] found exosomes carrying LMP1 in blood and saliva from the nasopharynx of cancer patients. Houali et al. [105] detected LMP1 and BARF1 coded by EBV in serum and saliva from teenagers and adults, and in adult nasopharyngeal cancer patients' serum and saliva at $62 \%$ and $100 \%$, respectively. Animal experiments demonstrated that LMP1 secretion was related to exosomes. Both proteins were good markers for nasopharyngeal cancer diagnosis, especially BARF1, because it covered the entire age range. Their pro-mitotic activities facilitated the occurrence and development of nasopharyngeal cancer. Abundant LMP1 was also detected in exosomes from EBVinfected nasopharyngeal cancer cells [106]. Cancer exosomes could be continuously detected in the plasma of nasopharyngeal cancer patients. Furthermore, the increase in serum exosomal concentration of nasopharyngeal cancer patients was closely related to terminal-stage lymphatic metastasis and poor prognosis [107].

\section{Correlation between exosomal proteins as biomarkers and digestive system disease Pancreatic cancer}

Glypican-1 (GPC1)-positive exosome is a diagnostic index of early stage pancreatic cancer [42]. Circulating exosomes containing GPC1 (GPC1 + Exos) were isolated from blood of 250 pancreatic cancer patients, which helped to distinguish between chronic pancreatitis and pancreatic cancer patients (in early and terminal stages). In animal experiments, GPC1 + Exos in blood were significantly increased, before cancer imaging could be used. Furthermore, 


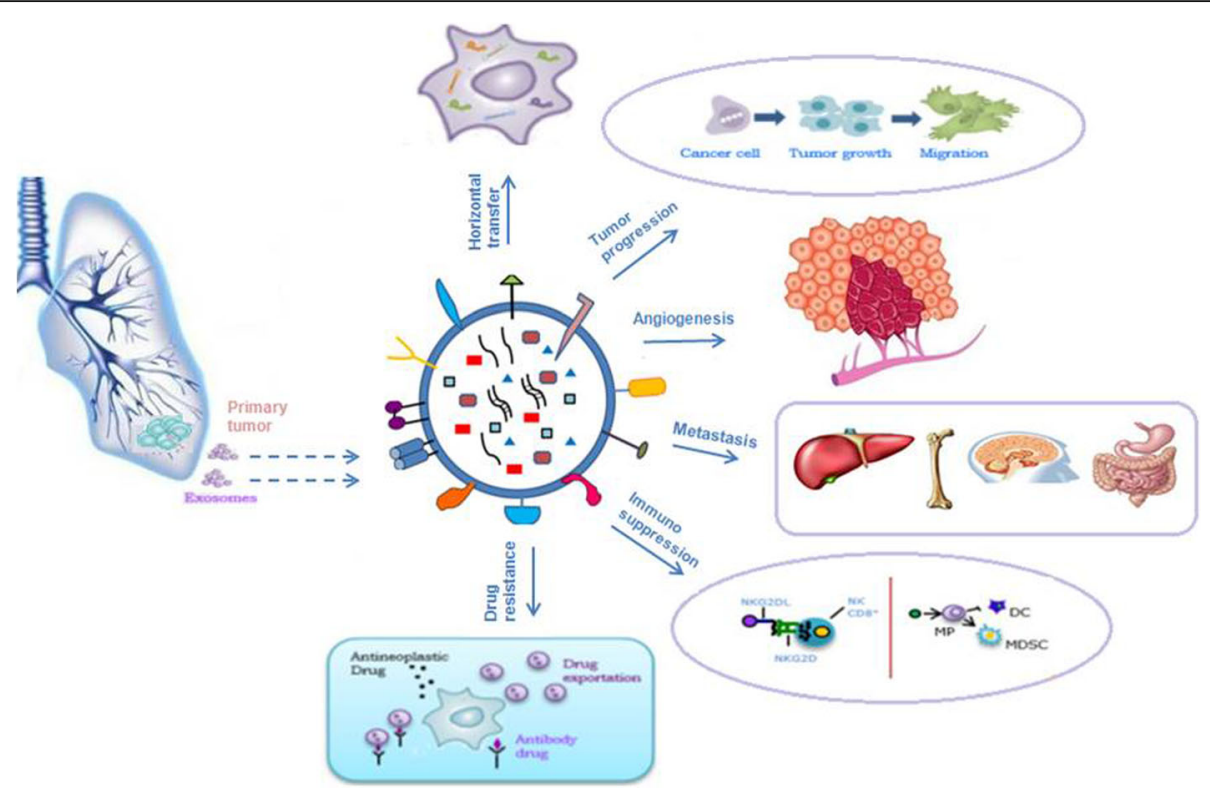

Fig. 3 Role of exosomes in NSCLC. Exosomes have a key role in: 1 horizontal transfer of mRNAs and miRNAs from cancer cells to cells of microenvironment; 2 tumor progression, inducing cells motility; 3 angiogenesis; 4: metastatization; 5: immunosuppression; 6: drug resistance

GPC1-positive exosomes could also be used as a preoperative and postoperative prognostic index. GPC1 + Exos was a significantly better prognostic marker of pancreatic cancer than CA19-9. Thus, GPC1 + Exos could be used to diagnose pancreatic cancer at early and terminal stages with high accuracy and sensitivity, and as a detection index for therapy. Macrophage migration inhibitory factor (MIF) was found to promote hepatic metastasis of cancers, and could be used as an early stage diagnostic marker for pancreatic cancer hepatic metastasis.

\section{Liver cancer and cholangiocarcinoma}

A mouse liver damage model was established to analyze urinary exosomal proteomics [93]. Twenty-eight novel exosomes closely related to disease were found, in which CD26, CD81, S1C3A1 and CD10 could be used as markers for hepatic damage. In cholangiocarcinoma model caused by Opisthorchis viverrini, 154 proteins were disrupted after cancer onset. To find the specific marker for diagnosing cholangiocarcinoma caused by Opisthorchis viverrini in circulating body fluids, exosomes from peripheral circulation of patients were extracted and compared with those from cholangiocarcinoma cell line KKU055. Finally, 27 specific proteins were identified, which provided an experimental basis for cholangiocarcinoma diagnosis.

\section{Gastric cancer}

In 2015 , an estimated 24,590 people were diagnosed and 10,720 people eventually died of the disease in the United States [108]:As one of the most lethal cancers, gastric cancer (GC) is rampant in many countries around the world. GC is the fourth most common cancer and the second leading cause of cancer death, worldwide [109]. As a carrier, exosomes play an important function in the interaction between cancer cells, the vascular endothelial cells and the macrophages. Exosomes derived from GC cells could also stimulate the activation of the NF-kB pathway in macrophages to promote cancer progression [110]. Recent evidence has found that AZ-P7a, a metastatic GC cell line, released let-7 miRNAs via exosomes into the extracellular environment to maintain the oncogenesis [111]. The enrichment of let-7 miRNA family in the exosomes from AZ-P7a cells may reflect metastasis in GC. CD97 promotes $\mathrm{GC}$ cell proliferation and invasion in vitro through exosomes-mediated MAPK signaling pathway, and exosomal miRNAs are probably involved in the activation of the CD97-associated pathway [112]. the Cbl family of ubiquitin ligases might be involved in regulation of exosome-induced apoptosis of Jurkat $\mathrm{T}$ cells by increasing PI3K proteasome degradation, inactivation of PI3K/ Akt signaling, thus mediating some effects of caspase activation [113]: The role of tetraspanin 8-containing exosomes is associated with cell growth and invasion in GC; tetraspanin 8 is an independent prognostic factor in patients with GC [114]. The schematic representation of the role that exosomes play in GC carcinogenesis and metastasis is summarized in (Fig. 4).

$\mathrm{Gu}$ et al. suggested that $\mathrm{GC}$ cells triggered the differentiation of human umbilical cordderived mesenchymal stem cells to carcinoma-associated fibroblasts by exosomesmediated TGF- $\beta$ transfer and activation of the TGF- $\beta /$ 


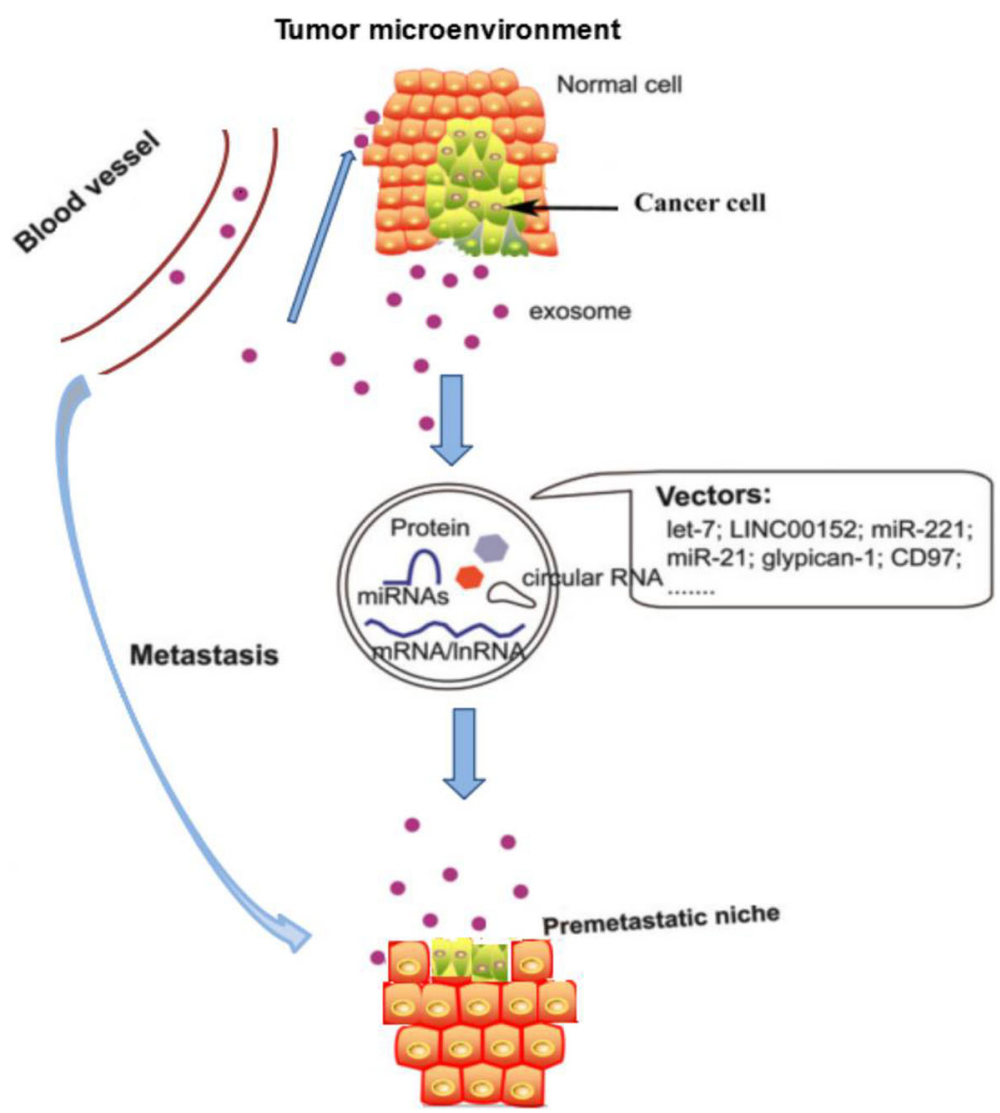

Fig. 4 The schematic representation of the role that exosomes play in gastric cancer carcinogenesis and metastasis is summarized in the figure

Smad pathway, which may represent a novel mechanism for MSCs-to- CAFs transition in cancer [115]. Furthermore, the $\mathrm{Cbl}$ family of ubiquitin ligases might be involved in regulation of exosome-induced apoptosis of Jurkat $\mathrm{T}$ cells by increasing PI3K proteasome degradation, inactivation of PI3K/ Akt signaling, thus mediating some effects of caspase activation [116]. Exosomes derived from human mesenchymal stem cells promote GC cell growth and migration via induction of the epithelial-mesenchymal transition and the activation of the Akt pathway [117]. CD97 promotes GC cell proliferation and invasion in vitro through exosomes-mediated MAPK signaling pathway, and exosomal miRNAs are probably involved in the activation of the CD97-associated pathway [118]. The role of tetraspanin 8-containing exosomes is associated with cell growth and invasion in GC; tetraspanin 8 is an independent prognostic factor in patients with GC. Additionally, TEX may play a critical role in the development of peritoneal metastases of GC, which may partially be due to the increased expression of the adhesion molecules fibronectin 1 (FN1) and laminin gamma 1 (LAMC1) in mesothelial cells [39]. The schematic representation of the role that exosomes play in GC carcinogenesis and metastasis is summarized in (Fig. 1).
Baran et al. [119] found that the number of exosomes was significantly higher in gastric cancer patients than in the normal control group. Expressions of human epidermal growth factor receptor (HER-2/neu) and human chemokine receptor-6 (CCR6) were significantly increased on exosomal surface in blood. Cancer markers such as HER2/neu, melanoma antigen (MAGE) and c-Met as well as extracellular matrix metalloproteinase inducer (EMMPRIN) could be detected in exosomes from normal controls and gastric cancer patients. However, the patients expressed higher levels of these markers, of which MAGE-1 and HER-2/neu mRNA had significantly higher expression in exosomes from gastric cancer patients.

\section{Colorectal cancer}

Adenomatous polyposis coli (APC) mutation was found in early stage colorectal cancer, invisible chromosome familial adenomatous polyposis and most sporadic colorectal cancers [120], and might lead to its occurrence and development. Comparison between SW480 cells transfecting APC gene plasmid and exosomal proteome secreted by SW480 cells showed that dickkopf-related protein 4 (DKK 4) was highly expressed in exosomes of SW480 cells transfecting APC gene plasmid. In these cells, methylation level 
of DKK 4 gene promoter was decreased, suggesting that colorectal epithelial cells might up-regulate DKK 4 transcription and expression by down-regulating methylation of DKK 4 gene promoter, and further promote occurrence and development of colorectal cancer by exosomes secreting DKK 4 and inducing APC gene mutation. The comparison of exosomal proteome between KRAS wild type DKS-8 cells of human colon adenocarcinoma cells DLD-1 and K-RAS mutant type DKO-1 cells indicated that DKS8 secreted by DKO-1 exosomes was not only significantly proliferated but its invasion capacity was also increased. These experiments demonstrated that colorectal cancer exosomes played a critical role in maintaining cancer cell survival, proliferation and invasion of microenvironment. Silva et al. [121] quantitatively detected plasma exosomes from 91 colorectal cancer patients and found that the number of exosomes was significantly higher than in the control group, and also significantly correlated with carcinoembryonic antigen (CEA). Thus, number of plasma exosomes in colorectal cancer patients can be used as a cancer marker that is closely related to disease development and poor prognosis.

\section{Correlation between exosomal proteins as biomarkers and nervous system disease \\ Parkinson's disease}

Fraser et al. [65] found leucine-rich repeat kinase 2 (LRRK2) as a biomarker in urinary exosomes from Parkinson's disease patients. They used ratio of ser-1292 LRRK2 to total LRRK2 to predict LRRK2 gene mutation status and Parkinson's disease risk in carriers of LRRK2 gene mutation, and found that ser-1292 LRRK2 was closely related to Parkinson's disease. Then they compared ser (P)-1292 LRRK2 levels in urine samples of 79 Parkinson's disease patients with 79 healthy controls and found that ser (P)-1292 level in urinary exosomes of primary Parkinson's disease patients was significantly increased as compared to controls, and was closely related to severity of the disease [122].

\section{Spongioblastoma}

The detection of serum exosomes from 25 spongioblastoma patients indicated the presence of a spongioblastomaspecific epidermal growth factor receptor variant type III (EGFRVII). Thus, detecting exosomes in blood derived from cancers could provide diagnostic information and adjuvant therapy for cancer patients [123]. Furthermore, micro-fluidic chip was used to analyze exosomal protein types in blood circulation of spongioblastoma patients. Exosomes containing EGFR-VII, EGFR, PDPN and IDH1 secreted by spongioblastoma were isolated, which confirmed that detection of circulating exosomes could predict efficacy of clinical drugs and cancer mutations [124].

\section{Correlation between exosomal proteins as biomarkers and genitourinary system disease Renal cell carcinoma}

Raimondo et al. [125] studied exosomes in urine samples from nine patients with renal cell carcinoma and 23 healthy controls, and found that matrix metalloproteinase 9 (MMP9), ceruloplasmin (Cp), podocalyxin (PC), DKK 4, and carbonic anhydrase IX (CAIX) were highly expressed. However, aquaporin-1 (AQP-1), extracellular matrix metalloproteinase inducer (EMMPRIN), neprily$\sin (\mathrm{CD} 10)$, dipeptidase 1 and syntenin-1 were repressed. Application of exosomal proteomics of 10 proteins has potential clinical value for early stage diagnosis of renal cell carcinoma.

\section{Bladder cancer}

Chen et al. [126] applied isotopic dimethylation labeling coupled with liquid chromatography-tandem mass spectrometry (LC-MS/MS) to identify bladder cancer biomarkers in urinary microparticles isolated from hernia (control) and bladder cancer patients. They identified 2964 proteins based on more than two distinct peptides, of which 2058 had not been previously reported as constituents of human urine exosomes/microparticles. A total of 107 differentially expressed proteins were identified as candidate biomarkers. Differences in the concentrations of 29 proteins (41 signature peptides) were precisely quantified by LC-MRM/MS in 48 urine samples of bladder cancer, hernia, and urinary tract infection/hematuria. Concentrations of 24 proteins changed significantly between bladder cancer and hernia. We quantified cancer-associated calcium-signal transducer 2 (TACSTD2) in raw urine specimens using a commercial ELISA and confirmed its potential value for diagnosis of bladder cancer. Our study revealed a strong association of TACSTD2 with bladder cancer and highlighted the potential of human urinary microparticles in the noninvasive diagnosis of bladder cancer. The expression of CD36 and CD44 in the exosomes was detected by immunoblotting and flow cytometry. The expression of CD36 and CD44 was significantly different between healthy and bladder cancer patients [115].

\section{Prostate cancer}

Nilsson et al. [127] found that urinary exosomes in patients with prostate cancer expressed $\beta$-catenin, prostate cancer gene-3 (PCA-3), transmembrane serine protease 2-ETS transcription factor family member-related gene fusion (TMPRSS2 -ERG) and other prostate cancerrelated markers. The expression of prostate specific antigen (PSA) and prostate specific membrane antigen (PSMA) was also detected in urinary exosomes of patients with prostate cancer showing the potential for diagnosis and monitoring of cancer patients. 


\section{Ovarian cancer}

Ovarian cancer is one of the most lethal forms of cancer in women, and until recently, lacked consistent biomarkers useful for its detection. Approximately 70\% of cases of ovarian cancer are diagnosed in advanced stage, which has only a $20 \%$ survival rate within 5 years of diagnosis. However, if diagnosed at early stage (at Stage I), survival rate is over 90\% [67]. Therefore, early diagnosis using exosomal contents may be highly important and may save large number of patients dying from ovarian cancer due to late diagnosis.

Recent discoveries of epithelial cell adhesion molecule (EpCAM) and CD24 in ovarian cancer-derived exosomes have been highly promising alternatives for early detection of ovarian cancer. EpCAM is a glycoprotein that facilitates homo-typical adhesion of cells. It has been found in pseudo-stratified, transitional and simple epithelia on the basolateral surfaces and has been identified as a cargo protein in exosomes.CD24 is recognized as a cancer marker and is associated with poor prognosis of ovarian carcinomas. CD24 can also be found in the cytoplasm inside MVBs and released into the extracellular environment via exosomes, in which case it is correlated with more aggressive forms of ovarian carcinoma, worsening the prognoses and therefore, shortening patients' survival times [128].In the exosomes isolated from sera of ovarian cancer patients, Li et al. [97] found that epithelial ovarian cancer markers (such as Claudin 4) gradually increased with the development of cancer. Szajnik et al. [129] found that L1CAM, CD24, ADAM10, EMMPRIN, TGF 31 , MAGE3/ 6 and Claudin-4 in peripheral blood exosomes could facilitate early stage diagnosis of ovarian cancer. Exosomal proteomics research $[130,131]$ indicated that exosomes in ovarian cancer had abundant cancer occurrence and development-related proteins of the integrin pathway, EGF receptor pathway, Wnt signaling pathway, PI3 kinase pathway, Fgf receptor pathway, Ras, p53 and angiogenic pathway, including phosphorylated and acetylated proteins. These proteins played a very important role in regulating communication between cells and matrix. In depth study of interactions between these molecules and their functions in signal transduction pathways may demonstrate the molecular mechanisms of malignant cancer occurrence and development.

\section{Correlation between exosomal proteins as biomarkers and other cancers}

Exosomal proteins are used as biomarkers in breast cancer cells, melanoma cells and multiple myeloma cells. Melo et al. [132].revealed that miRNA biogenesis in exosomes inhibited the expression of their respective mRNA targets, such as phosphatase and tensin homolog (PTEN) and the transcription factor homeobox D10 (HOXD10), indicating the contribution to breast cancer progression. Persistent increase in CEA and cancer antigen 15-3 levels in exosomes from breast cancer patients is closely related to the number of cancer foci [116]. Comparison of exosomal proteomics between breast cancer cells lines MCF-7 and MDA-MB231 showed that MDA-MB231 exosomes had a high level of matrix metalloproteinase, which was related to its strong metastasis [116]. A study using exosomes in blood to detect occurrence, development and relapse of breast cancer [117] indicated that the number of exosomes increased with cancer invasion ability. Therefore, markers from exosomes may be discovered earlier than biopsy, MRI or breast $\mathrm{X}$ ray to detect breast cancer. In serum exosomes from 40 breast cancer patients [118], survivin level was significantly increased, so survivin-2B can be used as a marker for breast cancer diagnosis or prognosis. More specifically, melanomaderived exosomes have been shown to promote metastasis through the preparation of the metastatic niche by the activation of bone marrow-derived progenitor cells [133]. Wolfers et al. [17] found that exosomes secreted by melanoma contained complete cancer antigen, which could activate CD8+ T cells and exhibit anti-cancer activity after being taken up by dendritic cells. Logozzi et al. [134] suggested that CD63 in plasma exosomes could be used as a protein marker for melanoma.

\section{Prospects}

Early stage cancer diagnosis is very important, which can extend lifespan and decrease disease-related death. Exosomes have become a research hotspot as biomarkers for disease diagnosis. On January 21, 2016, the first worldwide cancer diagnostic product based on exosomes was marketed in USA. The liquid biopsy products launched by Exosome Diagnostics marked a new step in exosomal biology [135]. Exosomal membrane and cytomembrane have the same homology. Using a known cancer surface marker antibody fixed on a chip, exosome surface markers in cell and plasma were detected, and about $40 \%$ of cancer cell surface markers were found on the exosomal surface [136] suggesting that the detection of exosomal surface markers could partially replace biopsy of cancer cells. As a biomarker, the exosome can provide abundant, stable, sensitive and specific biological information, and is a liquid biopsy specimen with high application value. However, cancer exosomal proteomics research is currently in its nascent stage. Accurate separation, identification and high throughput clinical application of extracellular vesicles are facing huge challenges. Further development of cancer exosomal proteomics as well as improvement of microfluidic techniques for detecting exosomes will certainly improve their usage for cancer diagnosis.

\section{Conclusions}

Exosomes play critical roles in almost all aspects of cancer provide opportunities for the development of exosomes as 
Table 1 Exosomes secreted in different body fluids and their potential cancer markers

\begin{tabular}{|c|c|c|c|}
\hline Cancer type & Potential Cancer Markers & Source & References \\
\hline Bladder Cancer & TACSTD2, EDIL-3, Mucin4, EPS8L2, a6-integrin, MUC-1, Basigin & Urine & [126] \\
\hline Breast cancer & Survivin, Survivin-2B, CEA, Ttumor antigen15-3 & Blood & {$[116,118]$} \\
\hline Colorectal cancer & CEA & Blood & \\
\hline Lung cancer & EpCAM, EGFR, CEA, LRG-1 & Blood & {$[100,101,137]$} \\
\hline Melanoma & CD63, Caveolin1, TYRP2, VLA-4, HSP70 & Blood & {$[133,134,139]$} \\
\hline Nasopharyngeal cancer & LMP1, Galectin-9, BARF-1 & Blood, Saliva & [103] \\
\hline Ovarian cancer & Claudin-4, L1CAM, CD24, ADAM10, EMMPRIN, TGFß1, MAGE3/6 & Blood & {$[97,129]$} \\
\hline Pancreatic cancer & GPC1, MIF & Blood & {$[42,138]$} \\
\hline Prostate cancer & $\begin{array}{l}\text { Transmembrane, protease, Serine2-ETS, } \beta \text {-catenin, PCA3, PSA, PSMA, ITGA3, ITGB1, } \\
\text { survivin, PTEN }\end{array}$ & Urine & {$[127,140]$} \\
\hline Renal cell carcinoma & MMP-9, EMMPRIN, Carbonic anhydrase & Urine & [125] \\
\hline Spongioblastoma & EGFR-VIII, EGFR, PDPN, IDH1 & Blood & {$[123,124,139]$} \\
\hline Stomach cancer & HER-2/neu, CCR6 & Blood & [119] \\
\hline
\end{tabular}

ideal diagnostic biomarkers and therapeutic targets. They are readily accessible in nearly all body fluids including blood, urine, saliva, and ascites and contain bioactive molecules that reflect the pathological state of the originated cells, thus providing an enriched source of biomarkers. Exosome-shuttled proteins and nucleic acids have been suggested as novel diagnostic and prognostic indicators for a variety of cancers (Table 1).

\section{Acknowledgments}

This study was funded by the National Natural Science Foundation of China (81603552) and Beijing health system high level talent project (2015-3-100); specific prediction and early stage diagnosis of molecular markers about liver cancer screening system and mechanism research platform (2016-2); The state administration of traditional Chinese medicine key disciplines of TCM infectious diseases; The infectious diseases key discipline of Beijing TCM and western medicine.

\section{Authors' contribution}

WHL and CYL were major contributors in writing the manuscript. DXC and $\mathrm{XHL}$ made substantial contributions to the design of the manuscript and revised it critically for important intellectual content. TZ created all the figures. XHL and XNL performed literature search. All authors have read and approved the final version of this manuscript.

\section{Competing interests}

The authors declare that they have no competing interests.

\section{Publisher's Note}

Springer Nature remains neutral with regard to jurisdictional claims in published maps and institutional affiliations.

\section{Author details}

${ }^{1}$ YouAn Hospital, Capital Medical University, Beijing, China. ${ }^{2}$ Beijing Institute of Hepatology, Beijing, China. ${ }^{3}$ Xinjiang Medical University, Wulumuqi, China. ${ }^{4} \mathrm{NO} .8$, xitoutiao,Youan men wai, Fengtai District, Beijing, China.

Received: 2 May 2017 Accepted: 1 August 2017

Published online: 29 August 2017

\section{References}

1. Mignot G, Roux S, Thery C, Segura E, Zitvogel L. Prospects for exosomes in immunotherapy of cancer. J Cell Mol Med. 2006;10:376-88.
2. Johnstone RM, Bianchini A, Teng K. Reticulocyte maturation and exosome release: transferrin receptor containing exosomes shows multiple plasma membrane functions. Blood. 1989;74:1844-51.

3. Fader CM, Savina A, Sanchez D, Colombo MI. Exosome secretion and red cell maturation: exploring molecular components involved in the docking and fusion of multivesicular bodies in K562 cells. Blood Cells Mol Dis. 2005;35:153-7.

4. Raposo G, Nijman HW, Stoorvogel W, Liejendekker R, Harding CV, Melief C, Geuze HJ. B lymphocytes secrete antigen-presenting vesicles. J Exp Med. 1996;183:1161-72.

5. Clayton A, Turkes A, Navabi H, Mason MD, Tabi Z. Induction of heat shock proteins in B-cell exosomes. J Cell Sci. 2005;118:3631-8.

6. Chaput N, Flament C, Viaud S, Taieb J, Roux S, Spatz A, Andre F, LePecq JB, Boussac M, Garin J, et al. Dendritic cell derived-exosomes: biology and clinical implementations. J Leukoc Biol. 2006;80:471-8.

7. Blanchard N, Lankar D, Faure F, Regnault A, Dumont C, Raposo G, Hivroz C. TCR activation of human $T$ cells induces the production of exosomes bearing the TCR/CD3/zeta complex. J Immunol. 2002;168:3235-41.

8. Zitvogel L, Regnault A, Lozier A, Wolfers J, Flament C, Tenza D, Ricciardi-Castagnoli P, Raposo G, Amigorena S. Eradication of established murine tumors using a novel cell-free vaccine: dendritic cell-derived exosomes. Nat Med. 1998;4:594-600.

9. Laulagnier K, Motta C, Hamdi S, Roy S, Fauvelle F, Pageaux JF, Kobayashi T, Salles JP, Perret B, Bonnerot C, Record M. Mast cell- and dendritic cellderived exosomes display a specific lipid composition and an unusual membrane organization. Biochem J. 2004;380:161-71.

10. Heijnen HF, Schiel AE, Fijnheer R, Geuze HJ, Sixma JJ. Activated platelets release two types of membrane vesicles: microvesicles by surface shedding and exosomes derived from exocytosis of multivesicular bodies and alphagranules. Blood. 1999;94:3791-9.

11. Skokos D, Botros HG, Demeure C, Morin J, Peronet R, Birkenmeier G, Boudaly S, Mecheri S. Mast cell-derived exosomes induce phenotypic and functional maturation of dendritic cells and elicit specific immune responses in vivo. J Immunol. 2003;170:3037-45.

12. Nguyen DG, Booth A, Gould SJ, Hildreth JE. Evidence that HIV budding in primary macrophages occurs through the exosome release pathway. J Biol Chem. 2003:278:52347-54.

13. Schorey JS, Bhatnagar S. Exosome function: from tumor immunology to pathogen biology. Traffic. 2008;9:871-81.

14. van Niel G, Heyman M. The epithelial cell cytoskeleton and intracellular trafficking. II. Intestinal epithelial cell exosomes: perspectives on their structure and function. Am J Physiol Gastrointest Liver Physiol. 2002;283:G251-5.

15. Van Niel G, Mallegol J, Bevilacqua C, Candalh C, Brugiere S, Tomaskovic-Crook E, Heath JK, Cerf-Bensussan N, Heyman M. Intestinal epithelial exosomes carry MHC class II/peptides able to inform the immune system in mice. Gut. 2003:52:1690-7.

16. Taylor DD, Gercel-Taylor C. Tumour-derived exosomes and their role in cancer-associated T-cell signalling defects. Br J Cancer. 2005;92:305-11.

17. Wolfers J, Lozier A, Raposo G, Regnault A, Thery C, Masurier C, Flament C, Pouzieux S, Faure F, Tursz T, et al. Tumor-derived exosomes are a source of shared tumor rejection antigens for CTL cross-priming. Nat Med. 2001;7:297-303. 
18. Riteau B, Faure F, Menier C, Viel S, Carosella ED, Amigorena S, Rouas-Freiss N. Exosomes bearing HLA-G are released by melanoma cells. Hum Immunol. 2003;64: 1064-72.

19. Andre F, Schartz NE, Chaput N, Flament C, Raposo G, Amigorena S, Angevin E, Zitvogel L. Tumor-derived exosomes: a new source of tumor rejection antigens. Vaccine. 2002;20(Suppl 4):A28-31.

20. Andre F, Schartz NE, Movassagh M, Flament C, Pautier P, Morice P, Pomel C, Lhomme C, Escudier B, Le Chevalier T, et al. Malignant effusions and immunogenic tumour-derived exosomes. Lancet. 2002;360:295-305.

21. van Niel G, Raposo G, Candalh C, Boussac M, Hershberg R, Cerf-Bensussan N, Heyman M. Intestinal epithelial cells secrete exosome-like vesicles. Gastroenterology. 2001;121:337-49.

22. Faure J, Lachenal G, Court M, Hirrlinger J, Chatellard-Causse C, Blot B, Grange J, Schoehn G, Goldberg Y, Boyer V, et al. Exosomes are released by cultured cortical neurones. Mol Cell Neurosci. 2006:31:642-8.

23. Ge R, Tan E, Sharghi-Namini S, Asada HH. Exosomes in cancer microenvironment and beyond: have we overlooked these extracellular messengers? Cancer Microenviron. 2012;5:323-32.

24. Keller S, Rupp C, Stoeck A, Runz S, Fogel M, Lugert S, Hager HD, AbdelBakky MS, Gutwein P, Altevogt P. CD24 is a marker of exosomes secreted into urine and amniotic fluid. Kidney Int. 2007;72:1095-102.

25. Li QL, Bu N, Yu YC, Hua W, Xin XY. Exvivo experiments of human ovarian cance ascites-derived exosomes presented by dendritic cells derived from umbilical cord blood for immunotherapy treatment. Clin Med Oncol. 2008;2:461-7.

26. Taylor DD, Gercel-Taylor C. MicroRNA signatures of tumor-derived exosomes as diagnostic biomarkers of ovarian cancer. Gynecol Oncol. 2008;110:13-21.

27. Almqvist N, Lonnqvist A, Hultkrantz S, Rask C, Telemo E. Serum-derived exosomes from antigen-fed mice prevent allergic sensitization in a model of allergic asthma. Immunology. 2008;125:21-7.

28. Gallo A, Tandon M, Alevizos I, Illei GG. The majority of microRNAs detectable in serum and saliva is concentrated in exosomes. PLoS One. 2012;7:e30679.

29. Ogawa Y, Kanai-Azuma M, Akimoto Y, Kawakami H, Yanoshita R. Exosomelike vesicles with dipeptidyl peptidase IV in human saliva. Biol Pharm Bull. 2008:31:1059-62

30. Navabi H, Croston D, Hobot J, Clayton A, Zitvogel L, Jasani B, Bailey-Wood R, Wilson K, Tabi Z, Mason MD, Adams M. Preparation of human ovarian cancer ascites-derived exosomes for a clinical trial. Blood Cells Mol Dis. 2005;35:149-52.

31. Admyre C, Johansson SM, Qazi KR, Filen JJ, Lahesmaa R, Norman M, Neve EP, Scheynius A, Gabrielsson S. Exosomes with immune modulatory features are present in human breast milk. J Immunol. 2007;179:1969-78.

32. Saman S, Kim W, Raya M, Visnick Y, Miro S, Saman S, Jackson B, McKee AC, Alvarez VE, Lee NC, Hall GF. Exosome-associated tau is secreted in tauopathy models and is selectively phosphorylated in cerebrospinal fluid in early Alzheimer disease. J Biol Chem. 2012;287:3842-9.

33. Street JM, Barran PE, Mackay CL, Weidt S, Balmforth C, Walsh TS, Chalmers RT, Webb DJ, Dear JW. Identification and proteomic profiling of exosomes in human cerebrospinal fluid. J Transl Med. 2012;10:5

34. Qiu S, Duan X, Geng X, Xie J, Gao H. Antigen-specific activities of CD8+ T cells in the nasal mucosa of patients with nasal allergy. Asian Pac J Allergy Immunol. 2012:30:107-13.

35. De Toro J, Herschlik L, Waldner C, Mongini C. Emerging roles of exosomes in normal and pathological conditions: new insights for diagnosis and therapeutic applications. Front Immunol. 2015;6:203.

36. Meckes DJ. Exosomal communication goes viral. J Virol. 2015:89:5200-3.

37. Barteneva NS, Maltsev N, Vorobjev IA. Microvesicles and intercellular communication in the context of parasitism. Front Cell Infect Microbiol. 2013;3:49.

38. Kucharzewska P, Belting M. Emerging roles of extracellular vesicles in the adaptive response of tumour cells to microenvironmental stress. J Extracell Vesicles. 2013;2

39. Rak J. Extracellular vesicles - biomarkers and effectors of the cellular interactome in cancer. Front Pharmacol. 2013;4:21.

40. Hornick NI, Huan J, Doron B, Goloviznina NA, Lapidus J, Chang BH, Kurre P. Serum exosome MicroRNA as a minimally-invasive early biomarker of AML. Sci Rep. 2015:5:11295.

41. Tang MK, Wong AS. Exosomes: emerging biomarkers and targets for ovarian cancer. Cancer Lett. 2015:367:26-33.

42. Melo SA, Luecke LB, Kahlert C, Fernandez AF, Gammon ST, Kaye J, LeBleu VS, Mittendorf EA, Weitz J, Rahbari N, et al. Glypican-1 identifies cancer exosomes and detects early pancreatic cancer. Nature. 2015;523:177-82.
43. Li Y, Zheng Q, Bao C, Li S, Guo W, Zhao J, Chen D, Gu J, He X, Huang S. Circular RNA is enriched and stable in exosomes: a promising biomarker for cancer diagnosis. Cell Res. 2015;25:981-4.

44. Thery C, Zitvogel L, Amigorena S. Exosomes: composition, biogenesis and function. Nat Rev Immunol. 2002;2:569-79.

45. Hannafon BN, Ding WQ. Intercellular communication by exosome-derived microRNAs in cancer. Int J Mol Sci. 2013;14:14240-69.

46. Mathivanan S, Fahner CJ, Reid GE, Simpson RJ. ExoCarta 2012: database of exosomal proteins, RNA and lipids. Nucleic Acids Res. 2012;40:D1241-4.

47. Mathivanan S, Simpson RJ. ExoCarta: a compendium of exosomal proteins and RNA. Proteomics. 2009:9:4997-5000.

48. Mathivanan S, Ji H, Simpson RJ. Exosomes: extracellular organelles important in intercellular communication. J Proteome. 2010;73:1907-20.

49. van Niel G, Porto-Carreiro I, Simoes S, Raposo G. Exosomes: a common pathway for a specialized function. J Biochem. 2006:140:13-21.

50. Michael A, Bajracharya SD, Yuen PS, Zhou H, Star RA, Illei GG, Alevizos I. Exosomes from human saliva as a source of microRNA biomarkers. Oral Dis. 2010;16:34-8.

51. Trams EG, Lauter CJ, Salem NJ, Heine U. Exfoliation of membrane ectoenzymes in the form of micro-vesicles. Biochim Biophys Acta. 1981;645:63-70.

52. Turchinovich A, Weiz L, Langheinz A, Burwinkel B. Characterization of extracellular circulating microRNA. Nucleic Acids Res. 2011;39:7223-33.

53. Gibbings DJ, Ciaudo C, Erhardt M, Voinnet O. Multivesicular bodies associate with components of miRNA effector complexes and modulate miRNA activity. Nat Cell Biol. 2009:11:1143-9.

54. Balaj L, Lessard R, Dai L, Cho YJ, Pomeroy SL, Breakefield XO, Skog J. Tumour microvesicles contain retrotransposon elements and amplified oncogene sequences. Nat Commun. 2011;2:180.

55. Salido-Guadarrama I, Romero-Cordoba S, Peralta-Zaragoza O, HidalgoMiranda A, Rodriguez-Dorantes M. MicroRNAs transported by exosomes in body fluids as mediators of intercellular communication in cancer. Onco Targets Ther. 2014;7:1327-38.

56. van der Pol E, Boing AN, Harrison P, Sturk A, Nieuwland R. Classification, functions, and clinical relevance of extracellular vesicles. Pharmacol Rev. 2012;64:676-705.

57. Trajkovic K, Hsu C, Chiantia S, Rajendran L, Wenzel D, Wieland F, Schwille P, Brugger B, Simons M. Ceramide triggers budding of exosome vesicles into multivesicular endosomes. Science. 2008;319:1244-7.

58. Baietti MF, Zhang Z, Mortier E, Melchior A, Degeest G, Geeraerts A, Ivarsson $Y$, Depoortere $F$, Coomans $C$, Vermeiren $E$, et al. Syndecan-syntenin-ALIX regulates the biogenesis of exosomes. Nat Cell Biol. 2012;14:677-85.

59. Miyanishi M, Tada K, Koike M, Uchiyama Y, Kitamura T, Nagata S. Identification of Tim4 as a phosphatidylserine receptor. Nature. 2007;450:435-9.

60. Segura E, Nicco C, Lombard B, Veron P, Raposo G, Batteux F, Amigorena S, Thery C. ICAM-1 on exosomes from mature dendritic cells is critical for efficient naive T-cell priming. Blood. 2005;106:216-23.

61. Zhang X, Yuan X, Shi H, Wu L, Qian H, Xu W. Exosomes in cancer: small particle, big player. J Hematol Oncol. 2015;8:83.

62. Kosaka N. Decoding the secret of cancer by means of extracellular vesicles. J Clin Med. 2016;5:22.

63. Roma-Rodrigues C, Fernandes AR, Baptista PV. Exosome in tumour microenvironment: overview of the crosstalk between normal and cancer cells. Biomed Res Int. 2014:2014:179486.

64. Minciacchi VR, Freeman MR, Di Vizio D. Extracellular vesicles in cancer: exosomes, microvesicles and the emerging role of large oncosomes. Semin Cell Dev Biol. 2015;40:41-51.

65. Fraser KB, Moehle MS, Alcalay RN, West AB. Urinary LRRK2 phosphorylation predicts parkinsonian phenotypes in G2019S LRRK2 carriers. Neurology. 2016;86:994-9.

66. Kucharzewska P, Christianson HC, Welch JE, Svensson KJ, Fredlund E, Ringner M, Morgelin M, Bourseau-Guilmain E, Bengzon J, Belting M. Exosomes reflect the hypoxic status of glioma cells and mediate hypoxiadependent activation of vascular cells during tumor development. Proc Natl Acad Sci U S A. 2013:110:7312-7.

67. Khalyfa A, Almendros I, Gileles-Hillel A, Akbarpour M, Trzepizur W, Mokhlesi B, Huang L, Andrade J, Farre R, Gozal D. Circulating exosomes potentiate tumor malignant properties in a mouse model of chronic sleep fragmentation. Oncotarget. 2016:7:54676-90.

68. Katoh M. Therapeutics targeting angiogenesis: genetics and epigenetics, extracellular miRNAs and signaling networks (review). Int J Mol Med. 2013; 32:763-7. 
69. Hood JL. Melanoma exosome induction of endothelial cell GM-CSF in premetastatic lymph nodes may result in different M1 and M2 macrophage mediated angiogenic processes. Med Hypotheses. 2016;94:118-22.

70. DeRita RM, Zerlanko B, Singh A, Lu H, lozzo RV, Benovic JL, Languino LR. CSrc, insulin-like growth factor I receptor, G-protein-coupled receptor Kinases and focal adhesion Kinase are enriched into prostate cancer cell Exosomes. J Cell Biochem. 2017;118:66-73.

71. Wang J, De Veirman K, Faict S, Frassanito MA, Ribatti D, Vacca A, Menu E. Multiple myeloma exosomes establish a favourable bone marrow microenvironment with enhanced angiogenesis and immunosuppression. J Pathol. 2016;239:162-73.

72. Konstantinell A, Bruun JA, Olsen R, Aspar A, Skalko-Basnet N, Sveinbjornsson $B$, Moens $U$. Secretomic analysis of extracellular vesicles originating from polyomavirus-negative and polyomavirus-positive Merkel cell carcinoma cell lines. Proteomics. 2016;16:2587-91.

73. Thakur BK, Zhang H, Becker A, Matei I, Huang Y, Costa-Silva B, Zheng Y, Hoshino A, Brazier H, Xiang J, et al. Double-stranded DNA in exosomes: a novel biomarker in cancer detection. Cell Res. 2014;24:766-9.

74. Zomer A, Maynard C, Verweij FJ, Kamermans A, Schafer R, Beerling E, Schiffelers RM, de Wit E, Berenguer J, Ellenbroek SI, et al. In vivo imaging reveals extracellular vesicle-mediated phenocopying of metastatic behavior. Cell. 2015;161:1046-57.

75. Endres M, Kneitz S, Orth MF, Perera RK, Zernecke A, Butt E. Regulation of matrix metalloproteinases (MMPs) expression and secretion in MDA-MB-231 breast cancer cells by LIM and SH3 protein 1 (LASP1). Oncotarget. 2016;7: 64244-59.

76. Sanchez CA, Andahur El, Valenzuela R, Castellon EA, Fulla JA, Ramos CG, Trivino JC. Exosomes from bulk and stem cells from human prostate cancer have a differential microRNA content that contributes cooperatively over local and pre-metastatic niche. Oncotarget. 2016;7:3993-4008.

77. Sceneay J, Smyth MJ, Moller A. The pre-metastatic niche: finding common ground. Cancer Metastasis Rev. 2013;32:449-64.

78. Gu J, Qian H, Shen L, Zhang X, Zhu W, Huang L, Yan Y, Mao F, Zhao C, Shi $Y, X u$ W. Gastric cancer exosomes trigger differentiation of umbilical cord derived mesenchymal stem cells to carcinoma-associated fibroblasts through TGF-beta/Smad pathway. PLoS One. 2012;7:e52465.

79. Tlsty TD, Hein PW. Know thy neighbor: stromal cells can contribute oncogenic signals. Curr Opin Genet Dev. 2001;11:54-9.

80. Orimo A, Gupta PB, Sgroi DC, Arenzana-Seisdedos F, Delaunay T, Naeem R, Carey VJ, Richardson AL, Weinberg RA. Stromal fibroblasts present in invasive human breast carcinomas promote tumor growth and angiogenesis through elevated SDF-1/CXCL12 secretion. Cell. 2005;121:335-48.

81. Antonyak MA, Li B, Boroughs LK, Johnson JL, Druso JE, Bryant KL, Holowka DA, Cerione RA. Cancer cell-derived microvesicles induce transformation by transferring tissue transglutaminase and fibronectin to recipient cells. Proc Natl Acad Sci U S A. 2011;108:4852-7.

82. Yang C, Ruffner MA, Kim SH, Robbins PD. Plasma-derived MHC class II+ exosomes from tumor-bearing mice suppress tumor antigen-specific immune responses. Eur J Immunol. 2012;42:1778-84.

83. Chornoguz O, Grmai L, Sinha P, Artemenko KA, Zubarev RA, OstrandRosenberg S. Proteomic pathway analysis reveals inflammation increases myeloid-derived suppressor cell resistance to apoptosis. Mol Cell Proteomics. 2011;10:M110-M2980.

84. Taylor DD, Gercel-Taylor C. Exosomes/microvesicles: mediators of cancerassociated immunosuppressive microenvironments. Semin Immunopathol. 2011;33:441-54

85. Condamine T, Gabrilovich DI. Molecular mechanisms regulating myeloid-derived suppressor cell differentiation and function. Trends Immunol. 2011;32:19-25.

86. Wang T, Diaz AJ, Yen Y. The role of peroxiredoxin II in chemoresistance of breast cancer cells. Breast Cancer (Dove Med Press). 2014;6:73-80.

87. Chen WX, Liu XM, Lv MM, Chen L, Zhao JH, Zhong SL, Ji MH, Hu Q, Luo Z, Wu JZ, Tang JH. Exosomes from drug-resistant breast cancer cells transmit chemoresistance by a horizontal transfer of microRNAs. PLoS One. 2014;9: e95240.

88. Bebawy M, Combes V, Lee E, Jaiswal R, Gong J, Bonhoure A, Grau GE. Membrane microparticles mediate transfer of P-glycoprotein to drug sensitive cancer cells. Leukemia. 2009;23:1643-9.

89. Safaei R, Larson BJ, Cheng TC, Gibson MA, Otani S, Naerdemann W, Howell SB. Abnormal lysosomal trafficking and enhanced exosomal export of cisplatin in drug-resistant human ovarian carcinoma cells. Mol Cancer Ther. 2005;4:1595-604
90. Boelens MC, Wu TJ, Nabet BY, Xu B, Qiu Y, Yoon T, Azzam DJ, Twyman-Saint VC, Wiemann BZ, Ishwaran $\mathrm{H}$, et al. Exosome transfer from stromal to breast cancer cells regulates therapy resistance pathways. Cell. 2014;159:499-513.

91. Penfornis P, Vallabhaneni KC, Whitt J, Pochampally R. Extracellular vesicles as carriers of microRNA, proteins and lipids in tumor microenvironment. Int J Cancer. 2016;138:14-21.

92. Boukouris S, Mathivanan S. Exosomes in bodily fluids are a highly stable resource of disease biomarkers. Proteomics Clin Appl. 2015;9:358-67.

93. He M, Zeng Y. Microfluidic exosome analysis toward liquid biopsy for cancer. J Lab Autom. 2016;21:599-608.

94. Frydrychowicz M, Kolecka-Bednarczyk A, Madejczyk M, Yasar S, Dworacki G. Exosomes - structure, biogenesis and biological role in non-small-cell lung cancer. Scand J Immunol. 2015;81:2-10.

95. Azmi AS, Bao B, Sarkar FH. Exosomes in cancer development, metastasis, and drug resistance: a comprehensive review. Cancer Metastasis Rev. 2013; 32:623-42.

96. Grange C, Tapparo M, Collino F, Vitillo L, Damasco C, Deregibus MC, Tetta C, Bussolati B, Camussi G. Microvesicles released from human renal cancer stem cells stimulate angiogenesis and formation of lung premetastatic niche. Cancer Res. 2011;71:5346-56.

97. Li J, Sherman-Baust CA, Tsai-Turton M, Bristow RE, Roden RB, Morin PJ. Claudin-containing exosomes in the peripheral circulation of women with ovarian cancer. BMC Cancer. 2009:9:244.

98. Rolfo C, Castiglia M, Hong D, Alessandro R, Mertens I, Baggerman G, Zwaenepoel K, Gil-Bazo I, Passiglia F, Carreca AP, et al. Liquid biopsies in lung cancer: the new ambrosia of researchers. Biochim Biophys Acta. 1846; 2014:539-46.

99. Clark DJ, Fondrie WE, Yang A, Mao L. Triple SILAC quantitative proteomic analysis reveals differential abundance of cell signaling proteins between normal and lung cancer-derived exosomes. J Proteome. 2016;133:161-9.

100. Jakobsen KR, Paulsen BS, Baek R, Varming K, Sorensen BS, Jorgensen MM. Exosomal proteins as potential diagnostic markers in advanced non-small cell lung carcinoma. J Extracell Vesicles. 2015;4:26659.

101. Li Y, Zhang Y, Qiu F, Qiu Z. Proteomic identification of exosomal LRG1: a potential urinary biomarker for detecting NSCLC. Electrophoresis. 2011;32:1976-83.

102. Sandfeld-Paulsen B, Jakobsen KR, Baek R, Folkersen BH, Rasmussen TR, Meldgaard P, Varming K, Jorgensen MM, Sorensen BS. Exosomal proteins as diagnostic biomarkers in lung cancer. J Thorac Oncol. 2016;11:1701-10.

103. Keryer-Bibens C, Pioche-Durieu C, Villemant C, Souquere S, Nishi N, Hirashima M, Middeldorp J, Busson P. Exosomes released by EBV-infected nasopharyngeal carcinoma cells convey the viral latent membrane protein 1 and the immunomodulatory protein galectin 9. BMC Cancer. 2006;6:283.

104. Klibi J, Niki T, Riedel A, Pioche-Durieu C, Souquere S, Rubinstein E, Le Moulec S, Guigay J, Hirashima M, Guemira F, et al. Blood diffusion and Th1-suppressive effects of galectin-9-containing exosomes released by Epstein-Barr virusinfected nasopharyngeal carcinoma cells. Blood. 2009;113:1957-66.

105. Houali K, Wang X, Shimizu Y, Djennaoui D, Nicholls J, Fiorini S, Bouguermouh A, Ooka T. A new diagnostic marker for secreted Epstein-Barr virus encoded LMP1 and BARF1 oncoproteins in the serum and saliva of patients with nasopharyngeal carcinoma. Clin Cancer Res. 2007;13:4993-5000.

106. Meckes DJ, Shair KH, Marquitz AR, Kung CP, Edwards RH, Raab-Traub N. Human tumor virus utilizes exosomes for intercellular communication. Proc Natl Acad Sci U S A. 2010;107:20370-5.

107. Ye SB, Li ZL, Luo DH, Huang BJ, Chen YS, Zhang XS, Cui J, Zeng YX, Li J. Tumor-derived exosomes promote tumor progression and T-cell dysfunction through the regulation of enriched exosomal microRNAs in human nasopharyngeal carcinoma. Oncotarget. 2014;5:5439-52.

108. Siegel RL, Miller KD, Jemal A. Cancer statistics, 2015. CA Cancer J Clin. 2015;65:5-29.

109. Ferlay J, Steliarova-Foucher E, Lortet-Tieulent J, Rosso S, Coebergh JW, Comber H, Forman D, Bray F. Cancer incidence and mortality patterns in Europe: estimates for 40 countries in 2012. Eur J Cancer. 2013;49:1374-403.

110. Wu L, Zhang X, Zhang B, Shi H, Yuan X, Sun Y, Pan Z, Qian H, Xu W. Exosomes derived from gastric cancer cells activate NF-kappaB pathway in macrophages to promote cancer progression. Tumour Biol. 2016;37:12169-80.

111. Ohshima K, Inoue K, Fujiwara A, Hatakeyama K, Kanto K, Watanabe Y, Muramatsu K, Fukuda Y, Ogura S, Yamaguchi K, Mochizuki T. Let-7 microRNA family is selectively secreted into the extracellular environment via exosomes in a metastatic gastric cancer cell line. PLoS One. 2010;5:e13247.

112. Li C, Liu DR, Li GG, Wang HH, Li XW, Zhang W, Wu YL, Chen L. CD97 promotes gastric cancer cell proliferation and invasion through exosomemediated MAPK signaling pathway. World J Gastroenterol. 2015;21:6215-28. 
113. Qu JL, Qu XJ, Qu JL, Qu XJ, Zhao MF, Teng YE, Zhang Y, Hou KZ, Jiang YH, Yang $X H$, Liu YP. The role of cbl family of ubiquitin ligases in gastric cancer exosome-induced apoptosis of Jurkat T cells. Acta Oncol. 2009;48:1173-80.

114. Anami K, Oue N, Noguchi T, Sakamoto N, Sentani K, Hayashi T, Naito Y, Oo HZ, Yasui W. TSPAN8, identified by Escherichia Coli ampicillin secretion trap, is associated with cell growth and invasion in gastric cancer. Gastric Cancer. 2016;19:370-80

115. Welton JL, Khanna S, Giles PJ, Brennan P, Brewis IA, Staffurth J, Mason MD, Clayton A. Proteomics analysis of bladder cancer exosomes. Mol Cell Proteomics. 2010;9:1324-38.

116. Toth B, Nieuwland R, Liebhardt S, Ditsch N, Steinig K, Stieber P, Rank A, Gohring P, Thaler CJ, Friese K, Bauerfeind I. Circulating microparticles in breast cancer patients: a comparative analysis with established biomarkers. Anticancer Res. 2008;28:1107-12.

117. Meehan K, Vella $\amalg$. The contribution of tumour-derived exosomes to the hallmarks of cancer. Crit Rev Clin Lab Sci. 2016;53:121-31.

118. Khan S, Bennit HF, Turay D, Perez M, Mirshahidi S, Yuan Y, Wall NR. Early diagnostic value of survivin and its alternative splice variants in breast cancer. BMC Cancer. 2014;14:176.

119. Baran J, Baj-Krzyworzeka M, Weglarczyk K, Szatanek R, Zembala M, Barbasz J, Czupryna A, Szczepanik A, Zembala M. Circulating tumour-derived microvesicles in plasma of gastric cancer patients. Cancer Immunol Immunother. 2010;59:841-50.

120. Lim JW, Mathias RA, Kapp EA, Layton MJ, Faux MC, Burgess AW, Ji H, Simpson RJ. Restoration of full-length APC protein in SW480 colon cancer cells induces exosome-mediated secretion of DKK-4. Electrophoresis. 2012; 33:1873-80.

121. Silva J, Garcia V, Rodriguez M, Compte M, Cisneros E, Veguillas P, Garcia JM, Dominguez G, Campos-Martin Y, Cuevas J, et al. Analysis of exosome release and its prognostic value in human colorectal cancer. Genes Chromosomes Cancer. 2012;51:409-18.

122. Fraser KB, Rawlins AB, Clark RG, Alcalay RN, Standaert DG, Liu N, West AB. Ser(P)-1292 LRRK2 in urinary exosomes is elevated in idiopathic Parkinson's disease. Mov Disord. 2016;31:1543-50.

123. Skog J, Wurdinger T, van Rijn S, Meijer DH, Gainche L, Sena-Esteves M, Curry WJ, Carter BS, Krichevsky AM, Breakefield XO. Glioblastoma microvesicles transport RNA and proteins that promote tumour growth and provide diagnostic biomarkers. Nat Cell Biol. 2008;10:1470-6.

124. Shao H, Chung J, Balaj L, Charest A, Bigner DD, Carter BS, Hochberg FH, Breakefield XO, Weissleder $\mathrm{R}$, Lee $\mathrm{H}$. Protein typing of circulating microvesicles allows real-time monitoring of glioblastoma therapy. Nat Med. 2012;18:1835-40.

125. Raimondo F, Morosi L, Corbetta S, Chinello C, Brambilla P, Della MP, Villa A Albo G, Battaglia C, Bosari S, et al. Differential protein profiling of renal cell carcinoma urinary exosomes. Mol BioSyst. 2013;9:1220-33.

126. Chen CL, Lai YF, Tang P, Chien KY, Yu JS, Tsai CH, Chen HW, Wu CC, Chung T, Hsu CW, et al. Comparative and targeted proteomic analyses of urinary microparticles from bladder cancer and hernia patients. J Proteome Res. 2012;11:5611-29.

127. Nilsson J, Skog J, Nordstrand A, Baranov V, Mincheva-Nilsson L, Breakefield $\mathrm{XO}$, Widmark A. Prostate cancer-derived urine exosomes: a novel approach to biomarkers for prostate cancer. Br J Cancer. 2009;100:1603-7.

128. Runz S, Keller S, Rupp C, Stoeck A, Issa Y, Koensgen D, Mustea A, Sehouli J, Kristiansen G, Altevogt P. Malignant ascites-derived exosomes of ovarian carcinoma patients contain CD24 and EpCAM. Gynecol Oncol. 2007;107: 563-71.

129. Szajnik M, Derbis $M$, Lach $M$, Patalas $P$, Michalak M, Drzewiecka H, Szpurek D, Nowakowski A, Spaczynski M, Baranowski W, Whiteside TL. Exosomes in plasma of patients with ovarian carcinoma: potential biomarkers of tumor progression and response to therapy. Gynecol Obstet (Sunnyvale). 2013; Suppl 4:3.

130. Liang B, Peng P, Chen S, Li L, Zhang M, Cao D, Yang J, Li H, Gui T, Li X, Shen $K$. Characterization and proteomic analysis of ovarian cancer-derived exosomes. J Proteome. 2013;80:171-82.

131. Sinha A, Ignatchenko V, Ignatchenko A, Mejia-Guerrero S, Kislinger T. Indepth proteomic analyses of ovarian cancer cell line exosomes reveals differential enrichment of functional categories compared to the $\mathrm{NCl} 60$ proteome. Biochem Biophys Res Commun. 2014:445:694-701.

132. Melo SA, Sugimoto H, O'Connell JT, Kato N, Villanueva A, Vidal A, Qiu L, Vitkin E, Perelman LT, Melo CA, et al. Cancer exosomes perform cell- independent microRNA biogenesis and promote tumorigenesis. Cancer Cell. 2014;26:707-21.

133. Peinado $H$, Aleckovic M, Lavotshkin S, Matei I, Costa-Silva B, Moreno-Bueno G, Hergueta-Redondo M, Williams C, Garcia-Santos G, Ghajar C, et al. Melanoma exosomes educate bone marrow progenitor cells toward a prometastatic phenotype through MET. Nat Med. 2012;18:883-91.

134. Logozzi M, De Milito A, Lugini L, Borghi M, Calabro L, Spada M, Perdicchio $M$, Marino ML, Federici $C$, lessi $E$, et al. High levels of exosomes expressing CD63 and caveolin-1 in plasma of melanoma patients. PLoS One. 2009;4: e5219.

135. Sheridan C. Exosome cancer diagnostic reaches market. Nat Biotechnol. 2016;34:359-60.

136. Belov L, Matic KJ, Hallal S, Best OG, Mulligan SP, Christopherson RI. Extensive surface protein profiles of extracellular vesicles from cancer cells may provide diagnostic signatures from blood samples. J Extracell Vesicles. 2016; 5:25355.

137. Yamashita T, Kamada H, Kanasaki S, Maeda $Y$, Nagano K, Abe $Y$, Inoue M, Yoshioka Y, Tsutsumi Y, Katayama S, et al. Epidermal growth factor receptor localized to exosome membranes as a possible biomarker for lung cancer diagnosis. Pharmazie. 2013;68:969-73.

138. Costa-Silva B, Aiello NM, Ocean AJ, Singh S, Zhang H, Thakur BK, Becker A, Hoshino A, Mark MT, Molina $\mathrm{H}$, et al. Pancreatic cancer exosomes initiate pre-metastatic niche formation in the liver. Nat Cell Biol. 2015;17:816-26.

139. Revenfeld AL, Baek R, Nielsen MH, Stensballe A, Varming K, Jorgensen M. Diagnostic and prognostic potential of extracellular vesicles in peripheral blood. Clin Ther. 2014:36:830-46.

140. Gamez-Valero A, Lozano-Ramos SI, Bancu I, Lauzurica-Valdemoros R, Borras FE. Urinary extracellular vesicles as source of biomarkers in kidney diseases. Front Immunol. 2015;6:6.

\section{Submit your next manuscript to BioMed Central and we will help you at every step:}

- We accept pre-submission inquiries

- Our selector tool helps you to find the most relevant journal

- We provide round the clock customer support

- Convenient online submission

- Thorough peer review

- Inclusion in PubMed and all major indexing services

- Maximum visibility for your research

Submit your manuscript at www.biomedcentral.com/submit
) Biomed Central 